\title{
The Magnificent of Geosites as Geoheritage Potential in Djuanda Grand Forest Park Area, Bandung, Indonesia
}

\author{
Achmad Djumarma Wirakusumah ${ }^{1 *}$, Heryadi Rachmat ${ }^{2}$, Hana Nur Aini $^{3}$ \\ ${ }^{1}$ Bandung Polythecnic of Energy and Mining \\ Jend. Sudirman St., No. 623., Bandung Kulon, Kota Bandung, Jawa Barat 40211, Indonesia \\ ${ }^{2}$ Indonesia Geotourism Society (MAGI) \\ Tebet Timur Dalam X St., No. 2, Tebet, Jakarta Selatan, 12820, Indonesia \\ ${ }^{3}$ Gajahmada University \\ Bulaksumur, Sleman, Daerah Istimewa Yogyakarta, 55281, Indonesia \\ *E-mail: ade.wirakusumah@gmail.com
}

Article received: 18 February 2021, revised: 26 February 2021, accepted: 26 February 2021

DOI: 10.51835/iagij.2021.1.1.25

\begin{abstract}
Djuanda Grand Forest Park (Tahura Djuanda) at Bandung, West Java Province, built-in 1985, has functioned as a conservation area concerning Indonesia's biodiversity. It is the first Grand Forest Park among 27 of them, which was built in Indonesia. In addition, Djuanda Grand Forest Park potential for geodiversity and geoheritage concerning the geological history of the Tangkuban Parahu volcano formation since ancient times, so that conservation is needed. The Indonesian Geological Association (IAGI), in collaboration with the Djuanda Grand Forest Park Institution and the Geological Agency, researched the geoheritage potential of the Djuanda Grand Forest Park for accelerating the Tahura Djuanda to be a geoheritage area. The method used in this study consist of inventorying, identifying, analyzing, and mapping each geodiversity/geoheritage. The finding is that the Djuanda Grand Forest Park area has seven geoheritage potentials: the Dago Waterfall Lava, Pahoehoe Lava, Lalay Waterfall Lava, Omas Waterfall Lava, Ignimbrite at "Gua Belanda" and "Gua Jepang" and the Kraton Cliff Fault Scarp. By establishing the Djuanda Grand Forest Park area as a geoheritage area will expose more information about the geological history of Tangkuban Parahu Volcano's formation through some interpretation boards (signboards) installed at each geoheritage location for conservation and education purposes through tourists visit points. In addition, West Java will be the second province to have a geoheritage after the Geoheritage of Pandeglang Regency, located in Banten Province.
\end{abstract}

Keywords: Tahura Djuanda, Tangkuban Parahu, conservation, education, geoheritage,

\section{INTRODUCTION}

The complex of Sunda volcano used to be had three volcano bodies, namely Sunda volcano (as the giant volcano), Burangrang volcano (a parasite volcano on the Sunda volcano), and Tangkuban parahu volcano. The last one mentioned is the youngest and the only active volcano among the three up to now. Tangkuban Parahu volcano (the "child" of Sunda volcano) is also one of 127 active volcanoes in Indonesia, located at North Bandung, West Java (Figure 1). Sunda volcano erupted catastrophically at about 105 k.years BP, producing a huge volume of pyroclastic flow or Ignimbrite deposits coinciding with Sunda Caldera formation [1]. The deposits spread out mainly to the south, southwest, northeast, and partly to the west and southeast areas of the Sunda Volcano [24].

The oldest pyroclastic deposit of Tangkuban Parahu was 40,750 years BP [1]. On the other hand, Tangkuban parahu produced basaltic- andesite lava flow in about 
40 k.years BP flowing towards the East, North-East, and south [5] shows unique geodiversity at some places along the Cikapundung river.

The existing Lembang fault (22 km long) is also an attractive geodiversity to be researched. It is closely related to the development of Sunda and Tangkuban parahu volcanoes forming. These unique geodiversities are located within the Djoeanda Grand Forest Park Area, Bandung, Indonesia. By proposing the Djuanda Grand Forest Park area as a geoheritage area will expose more information about the geological history of the formation of Sunda and Tangkuban Parahu volcanoes through some interpretation boards (signboards) installed at each geoheritage location for education purposes through tourists visit points.

\section{METHODOLOGY}

The method used in this study consist of inventory, identifying, analyzing, and mapping each geosites, which has geodiversity/geoheritage data of potential area based on field observation (Figure 1). These activities' objective was to find the distribution of geodiversities and potential geosites with unique features and characteristics. Geodiversity consists primarily of minerals, rocks, landscape, and geological processes. The Geoheritage is a generic but descriptive term applied to geosites or areas of geologic features having significant scientific, educational, or aesthetic values.

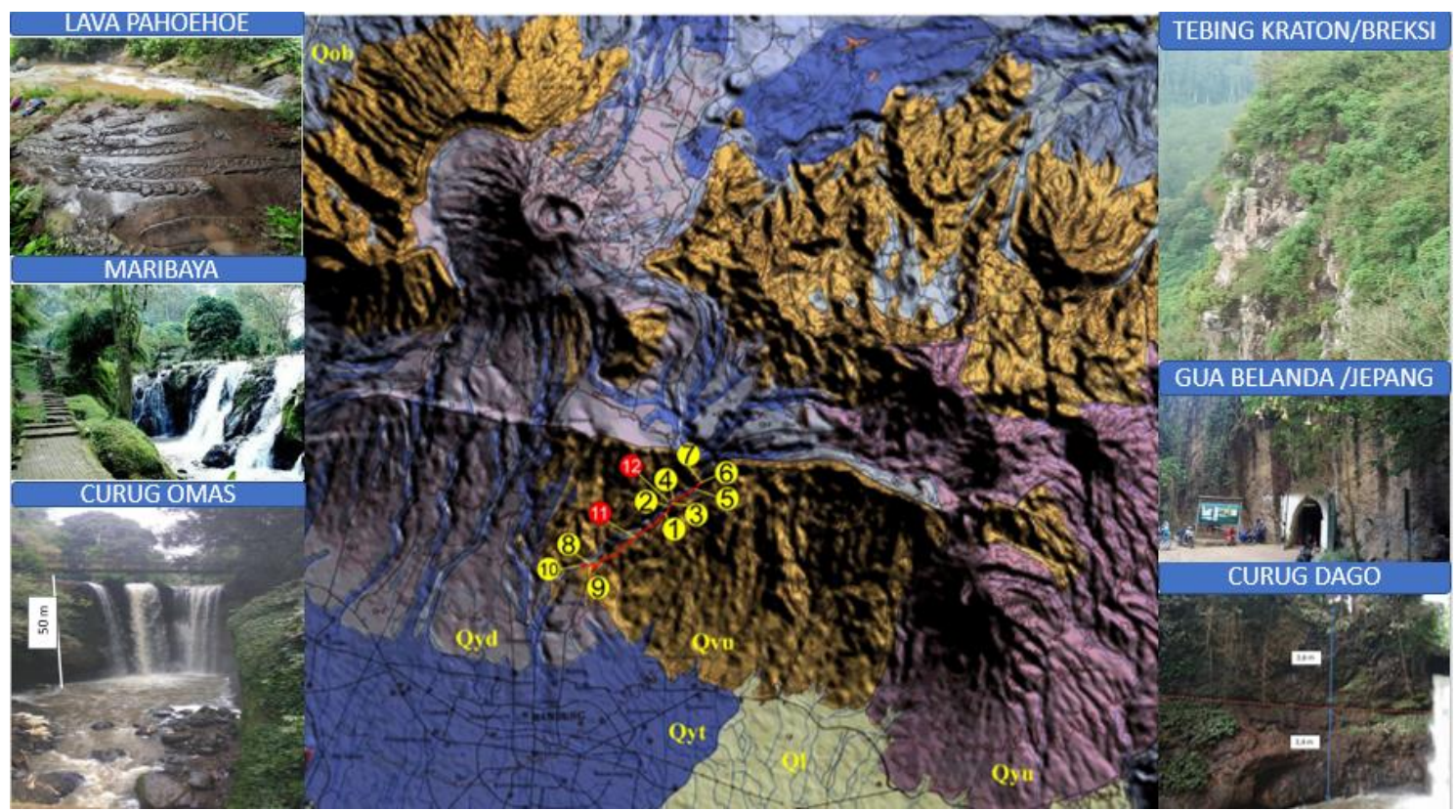

Figure 1. Location Map of Research Area.

\section{RESULTS AND DISCUSSION}

As the result of observing, identifying, analyzing, and mapping field inventory, we found at least seven unique geodiversities potentials, namely the Dago Waterfall lava, Pahoehoe Lava, Lalay Waterfall Lava, Omas
Waterfall Lava, Ignimbrite at "Gua Belanda" and "Gua Jepang", and Fault Scarps at Kraton and Gunung Batu. Accordingly, the most potential Geoheritages here are Sunda Ignimbrite, Tangkuban Parahu lava, and Lembang Fault. 


\section{Sunda Ignimbrite}

The Sunda Ignimbrite deposits are also found around the "Gua Belanda" and "Gua Jepang" area (Figure 2.) as the result of the Sunda catastrophic eruption, which was coinciding with Sunda Caldera formation in 105 k.years BP [1]. The giant ignimbrite [24] is a non-welded pyroclastic flow, composed of black scoria and grey to blackish pumice as juvenile material about
$20 \%$ of the whole volume, the rest of it consist of older material or lithic fragments from country rocks. The deposit thickness is about $33 \mathrm{~m}$ on average, covering a $200 \mathrm{~km}^{2}$ area with a volume of about $66 \mathrm{~km}^{3}$. The volume's value is almost the same as the value of the lost material of the Sunda summit part by reconstructing and assuming the summit of Sunda (before caldera-forming) was about 3000 masl.



Figure 2. Sunda Ignimbrite at "Gua Jepang".

\section{Tangkuban Parahu Lava}

Cikapundung River is located within Djuanda Grand Forest Park Area, northern Bandung. The river (Figure 3) is mainly covered by tuff, lapilli, volcanic bomb, and especially lava produced from Tangkuban Prahu Volcano. The lavas (39 and 40 k.years BP [5]) consist of basaltic andesite belonging to high K-series with high $\mathrm{Th} / \mathrm{Yb}(>3) . \mathrm{Ba} / \mathrm{La}$ (15-16) ratios indicate the involvement of subducted sediment into the magma genesis [6], causing depolymerization that will decrease magma viscosity and allowing Pāhoehoe lava type (Figure 4) to be produced [7]. A different kind from this basaltic andesite lava shows a ropy lava type found at "Waterfall of Lalay" (Figure 5) still at Cikapundung river.
These types of lava are scarce to find in convergent region types such as in Indonesia, Japan, etc., even they have not been being found in the world except at hotspot region types such as in Hawaii. A tongue of Tangkuban Parahu lava shows covering an old river deposit, conglomerate producing morphology of a $10 \mathrm{~m}$ high Dago Waterfall Cikapundung River (Figure 6). The lava also shows beautiful columnar joints. The same lava flow is also found at the same river to form the waterfall morphology, such as at Lalay Waterfall (5 $\mathrm{m}$ high) and Omas Waterfall (50 m high). Thus, this type of lava located at Djuanda Grand Forest Park Area can be classified into unique geodiversity. 
The Magnificent of Geosites as Geoheritage Potential

in Djuanda Grand Forest Park Area, Bandung, Indonesia

Achmad Djumarma Wirakusumah, et., al.



PETA GEOLOGI BANDUNG (Silitonga,1973)

Figure 3. Geological Maps Of Bandung [9].

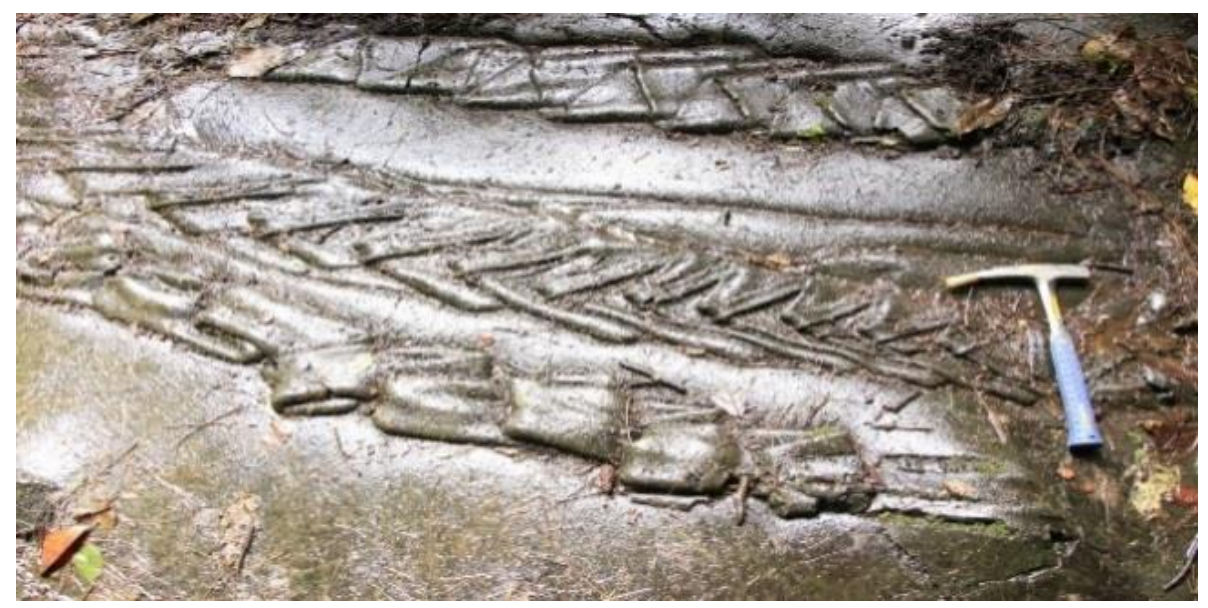

Figure 4. Out crop of Pahoehoe Lava type at Cikapundung river bank.

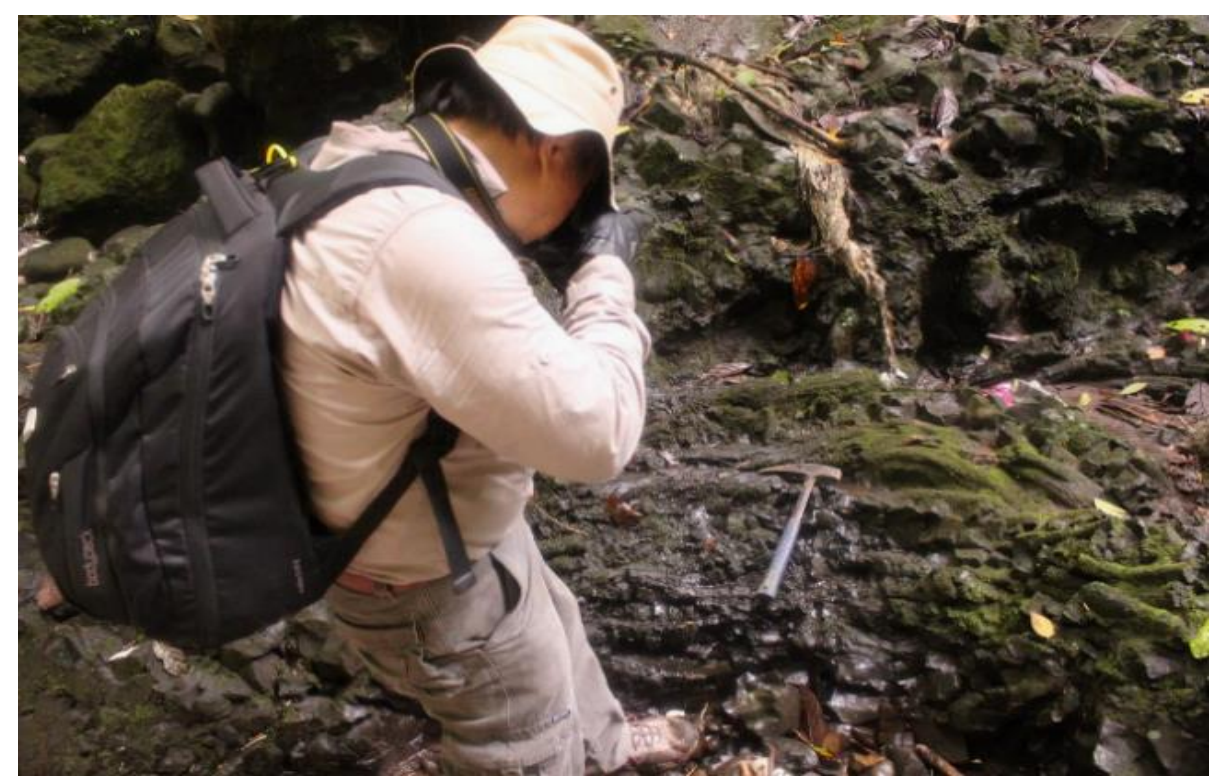

Figure 5. Out crop of ropy lava type at Water fall of Lalay. 




Figure 6. Tangkuban parahu lava covers conglomerate at "Dago Water Fall". The red dot line is the borderline between the two kinds of rock.

\section{Lembang Fault}

Tangkuban Parahu and Sunda volcanic complex are located close to the intersection between two faults (Fault of SukabumiPadalarang and Fault zone of CilacapKuningan) [8]. Lembang fault is a major fault in this area, stretching in an east-west direction. It is an active fault with a distinct northward facing scrap and can be traced along $22 \mathrm{~km}$ as a straight line from Mt. Pulusari in the east to the west near Cisarua [1]. The fault scarp of Lembang Fault can be seen at Tebing Keraton and Gunung Batu (Figure 7). The $50 \mathrm{~m}$ high Omas Waterfall forming is closely related to the development of Lembang activity. The Lembang fault was classified into a normal fault with the north block moves down and the south block goes up [9].



Figure 7. A Fault Scarp at Gunung Batu as a part of the Lembang Fault.

However, some experts considered that Lembang Fault is a normal left strip fault in the West area, and it is a normal fault in the East area. The development of the Lembang fault commenced after the Sunda Volcano's big eruption, which produced a huge deposit of ignimbrite. Installing a signboard at each geodiversity mentioned above, as shown in Figure 8, will increase the attractiveness of tourists in the Djuanda Grand Forest Park. 




Figure 8. A signboard has been installed at the gate of "Gua Belanda, for geotourism education purpose.

\section{CONCLUSIONS}

By proposing the Djuanda Grand Forest Park area as a geoheritage area, it will inform the tourist about geological history by installing an interpretation board (signboard) at each geoheritage location for geotourism education purposes. They are: (1) The evolution histories of Sunda Caldera and Tangkuban Parahu Volcano development; (2) The history of Pahoehoe Lava and ropy lava; (3) The history of waterfall formation (Dago Waterfall, Lalay Waterfall, and Omas Waterfall); and (4) The history of Lembang Fault. Accordingly, conservation of this area is needed.

\section{ACKNOWLEDGMENT}

The authors are grateful to Sandy, Ghazi, and Rena, for their critics and comments for this paper. The authors also thank the Insured Board of IAGI Journal for publishing this paper in the Journal.

\section{REFERENCES}

1. Kartadinata, M.N. Stratigraphy of Tephra Deposits from Tangkuban Perahu Volcano, West Java, Indonesia, Kagosima University, 2002.

2. Hadisantono, R.D. Project Report: Some Aspects of the Nature and Origin of the Widespread Pyroclastic Flow Deposits (Ignimbrites) Surrounding Tangkubanparahu, Bandung, West Java, Indonesia; New Zealand, 1988;

3. Sutoyo; Hadisantono, R.D. Geological Map of Tangkubanparahu Volcano/Sunda Complex Volcano, West Java; Bandung, 1992;

4. Dam, M.A.C. The Late Quaternary Evolution of Bandung Basin, West Java, Indonesia, Vrije Universiteit Amsterdam, 1994.

5. Sunardi, E.; Kimura, J. Temporal Chemical Variation in late Cenozoic Volcanic Rocks around Bandung Basin, West Java, Indonesia. J. Mineral. Petrol. Econ. Geol. 1998, 93, 103-128.

6. Abdurrachman, M. Geology and petrology of Quaternary Volcano and Genetic Relationship of Volcanic Rocks from the Triangular Volcanic Complex around Bandung Basin, West Java, Indonesia, Akita University, 2012.

7. Abdurrachman, M. Cikapundung Lava, West Java: an Example of the Pahoehoe Lava Type in Subduction System. In Proceedings of the Proceedings Geosea XIV Congress and 45th IAGI Annual Convention 2016 (GIC2016); IAGI: Bandung, 2016; hal. 4.

8. Katili, J.A.; Sudrajat, A. The $1982-1983$ Eruption of Mt. Galunggung of West Java, special issue VSI; 1984;

9. Silitonga Geological Map of the Bandung Quadrangle, Java, scale 1:100.000; Bandung, 1973; 